\title{
THE PROXY RULES: A CASE STUDY IN THE ADMINISTRATIVE PROCESS
}

\author{
Robert B. von Mehren* and John C. McCarroll $\dagger$
}

The development in the twentieth century of an increasingly complex urban industrial society in the United States has created new and different tasks for government. Many of these tasks involve regulation of segments of our economy and have been for the most part delegated to administrative agencies.

Professor Louis Jaffe has observed that delegation of power by the legislative branch of government is appropriate

... where there is agreement that a task must be performed and it cannot be effectively performed by the legislature without the assistance of a delegate or without an expenditure of time so great as to lead to the neglect of equally important business. Delegation is most commonly indicated where the relations to be regulated are highly technical or where their regulation requires a course of continuous decision. ${ }^{2}$

In 1934 Congress, by the Securities Exchange Act, created the Securities and Exchange Commission (SEC) to administer that act and the Securities Act of 1933. The congressional hearings which led to the passage of the r934 Act identified serious abuses in the prevailing proxy-solicitation practices. ${ }^{2}$ It was apparent to Congress that the relations to be regulated were highly technical and required a course of continuous supervision. Accordingly, in section I4 of the Securities Exchange Act of 1934, Congress delegated broad powers to the SEC to control the solicitation of proxies without specifying in detail the form or substance of such control. ${ }^{3}$ Section I4 makes unlawful the solicitation of proxies from holders of

* A.B. I942, Yale University; LL.B. 1946, Harvard University. Member of the New York bar.

† A.B. 1957, Princeton University; LL.B. I962, Harvard University. Member of the New York bar.

${ }^{1} \mathrm{Jaffe}$, An Essay on Delegation of Legislative Power, 47 Colum. L. REv. 359, 361 (1947).

2 "Fair corporate suffrage is an important right that should attach to every equity security bought on a public exchange. Managements of properties owned by the investing public should not be permitted to perpetuate themselves by the misuse of corporate proxies. Insiders having little or no substantial interest in the properties they manage have often retained their control without an adequate disclosure of their interest and without an adequate explanation of the management policies they intend to pursuc." H.R. REP. No. 1383, 73d Cong., 2d Sess. 13-I4 (I934). In its annual report for 1944, the SEC described the situation existing prior to the development of its proxy rules: "Prior to the development of the Commission's proxy rules, the average shareholder received annually from his company a proxy card in small type which he was urged to sign and return. Ordinarily, the proxy authorized some person or persons to vote the stockholders' shares to elect a board of directors and to take any other action which was considered desirable. Too frequently the owner of the shares was given no assurance that the items mentioned in the notice of meeting were the only ones which the management expected to bring up for consideration at the meeting. The stockholder was merely invited to sign his name and return his proxy without being furnished the information essential to the intelligent exercise of his right of franchise." ro SEC ANN. REP. 5I (I944).

${ }^{3}$ Securities Exchange Act of 1934 , ch. $404, \S \mathrm{r}_{4}(\mathrm{a}), 48$ Stat. 895 , $x_{5}$ U.S.C. $\$ 78 \mathrm{n}$ (a) (1958), provides as follows: "It shall be unlawful for any person, by the use of the mails or by any other means or instrumentality of interstate commerce or of any facility of any national securities exchange or otherwise to solicit or to permit the use of his name to solicit any proxy or consent or authorization in 
securities "registered on any national securities exchange in contravention of such rules and regulations as the Commission may prescribe as necessary or appropriate in the public interest or for the protection of investors." Thus, in effect, Congress left the entire problem of the nature, extent and form of federal proxy regulation for the SEC to consider and solve, and the proxy rules, as they have evolved since I935, represent the SEC's exercise of delegated power.

In this paper we shall consider the proxy rules as a case study in the administrative process. First, we shall review the way in which the proxy rules are administered by the Commission; then we shall consider how they have evolved from the very simple rules of 1935 to the much more complex rules of today; and, finally, we shall consider how compliance with the proxy rules is enforced:

\section{The Administration of the Proxy Rules}

A proxy is nothing more than the agency created when a corporate shareholder authorizes the proxy holder to cast the votes, to which the shareholder is entitled through his stock ownership, at a corporate meeting. Unlike most agencies in which the principal gives instructions to the agent, the agent holding a corporate proxy usually has far more information concerning the issues involved than his principal-the shareholder - and as a practical matter determines the matter with respect to which the agency will be created and the manner in which the agency will be carried out. This distortion of the ordinary principal-agent relation, a distortion inherent in the modern corporate structure, made possible the abuses which section I4 was designed to correct. Thus, the proxy rules promulgated by the Commission under section I4 are basically concerned with (a) the propositions with respect to which the agency (the proxy) is to be created (the resolutions to be considered at the corporate meeting), and (b) the facts which the shareholder must be given by those seeking his proxy so that he may have sufficient information to act intelligently.

respect of any security (other than an exempted security) registered on any national securities exchange in contravention of such rules and regulations as the Commission may prescribe as necessary or appropriate in the public interest or for the protection of investors." The Commission also regulates proxy solicitations under the Trust Indenture Act of I939, ch. 4II, $\$ 3$ I2(b), 53 Stat. II64. (I939), I5 U.S.C. $\$ 77 l l l(b)$ (I958), and the Investment Company Act of r940, ch. 686, $\$ \$ 20(a), 25,54$ Stat. 822,826 , 15 U.S.C. $\$ \$ 80 a-20$ (a), 80a-25 (I958).

The broad definition of "solicit" as used in $\$ \mathrm{I}_{4}$ can be seen by reference to the recent opinion of the Commission's General Counsel with respect to participation by broker-dealer firms in proxy solicitation. See Broker-Dealer Participation in Proxy Solicitations, SEC Securities Exxchange Act Release No. 7208, Jan. 7, I964.

' For a background discussion of corporate proxies, see Axe, Corporate Proxies, 4I Mick. L. REvi. $3^{8}$, 225 (I942). It is interesting to note that proxies are the creation of statutory law; the common law did not permit them. It is difficult to envision how the modern corporation could function and shareholders have the right to vote on matters such as the election of directors without the mechanism of the proxy being available. "As shareholders become more numerous and geographically dispersed, the proxy system becomes a practical necessity." Ralph J. Baker \& William L. Cary, Corporations i79 (3d ed. unabr. 1959). 
The administration of the proxy rules can best be analyzed in two principal contexts: the non-contested meeting and the contested meeting. Although the administrative procedures are basically the same, opposition to management, present in the contested meeting, causes some significant differences between the application of the proxy rules in the two situations.

\section{A. The Non-Contested Meeting}

For the most part, annual shareholders' meetings do not involve contests for corporate control. For example, during the fiscal year ended June 30, 1960, proxy statements in definitive form relating to 1,876 companies were filed with the SEC, but only twenty-five of these companies were involved in proxy contests for the election of directors; ${ }^{5}$ in fiscal 1961 , definitive proxy statements relating to 1,974 companies were filed, but only thirty-two were involved in proxy contests for the election of directors; ${ }^{6}$ and in fiscal 1962 , proxy statements in definitive form relating to 2,135 companies were filed, but only seventeen were involved in proxy contests for the election of directors. ${ }^{7}$ Under such circumstances, the annual meeting provides principally an opportunity for corporate management to report on its conduct of the business to the shareholders and to inform them of other matters which relate to the management of the corporation and the state of its affairs.

The hallmark of western political elections-the contest between opposing factions and the reliance on such opposition to develop relevant information-is generally absent from the corporate election, and the proxy rules relating to such uncontested annual meetings are principally designed to assure proper disclosure. Professor Louis Loss has commented on their usefulness:

The proxy rules are very likely the most effective disclosure device in the SEC scheme of things. The proxy literature, unlike the application for registration and the statutory reports, gets into the hand of investors. Unlike the Securities Act prospectus, it gets there in time. It is more readable than any of these other documents. And it gets to a good many people who never see a prospectus $\ldots .8^{8}$

The procedure which the Commission has developed for the handling of proxy materials in the absence of a contest is designed to guide corporate management in the performance of its legal obligation to make adequate disclosure to shareholders of relevant material concerning management's conduct of the affairs of the corporation. It is generally characterized by informality and flexibility. Commissioner Manuel F. Cohen has described these procedures:

526 SEC ANN. REP. 87, 88 (1960).

27 SEC ANN. REP. 7I, 73 (I96I).

228 SEC ANN. REP. 58, 60 (1962).

${ }^{8} 2$ Louts Loss, SECURITIES REGULATION 1027 (2d ed. 1961). Manuel F. Cohen, formerly a member of the staff of the Securities and Exchange Commission and now a member of the Commission, has said: "The primary underlying concept of the proxy rules-consistent with the philosophy of the statuteis that of disclosure. While the proxy regulation contains procedural rules of one kind or another, these are designed in the main to make effective the basic disclosure requirements and to permit frcer communication among security holders." Cohen, The SEC and Proxy Contests, 20 FED. B.J. 9r, 98 (1960). 
The rules require that the proxy statement be filed with the Commission in preliminary form ten days before its intended use. These periods may be, and often are, shortened by the Commission. This requirement provides a reasonable opportunity for review of the material by the Commission's staff and for appropriate correction when necessary before publication or other use. It is thus possible to avoid unnecessary expense or embarrassment which might otherwise arise if supplemental material to correct deficiencies in the proxy statement were required to be communicated to security holders. For similar reasons, and to permit a candid and free exchange between the staff of the Commission and the management or other persons soliciting proxies, the advance filing is not available for public inspection.

Since proxy material filed with the Commission may be mailed or otherwise employed by the solicitors within ten days after such filing and, in respect of follow-up materials, within two business days, the need for expeditious handling of such material is apparent. This situation is made more difficult by the fact that proxy solicitations have a marked seasonal peak which occurs during two or three months of the year. During the fiscal year ended June 30 , r959, material was filed with the Commission with respect to 1,975 solicitations, I,959 by management and 16 by others. This does not include the very substantial number of filings of follow-up material. The bulk of this material was filed during the months of February and March.

As already noted, the main emphasis of the rules is upon disclosure of pertinent and relevant information. It should be emphasized, moreover, that the Commission is not authorized to shape the nature of, or to pass upon, the merits of matters which are presented for action at meetings of security holders. Most proxy statements filed with the Commission relate to unopposed solicitation by the management seeking proxies to vote for its re-election or authorization for various types of corporate action such as charter or by-law amendment, merger, or assent to the issuance of debt securities. Expeditious scrutiny of those proxy statements is facilitated by referral of the material to staff members who are already familiar with the affairs of the particular issuer by reason of work on registration statements and reports filed under the various Acts. The problems encountered in the review of proxy statements are not unlike those found in the examination of registration statements, prospectuses and reports concerning which the staff has an accumulated experience. ${ }^{9}$

This description of the SEC's procedure emphasizes the very important role played by the staff in the administration of the proxy rules. The staff is not only expert in the general law relating to proxy solicitation but also has access to information (in most instances substantial) which the SEC has accumulated on the corporation involved. The staff's objectives should be to assist conscientious corporate management seeking to make the disclosures required by the rules and to compel compliance by any management attempting to avoid such disclosure. If problems

'Cohen, stipra note 8, at roI-02. The staff's comments are usually made in the form of a "letter of comment." This letter of comment will contain a detailed statement of the difficulties which the staff has with the material submitted. Frequently, the letter of comment will make affirmative suggestions as to how the stated objection might be corrected.

Sometimes the staff does not process proxy material in ten days but rather requests the filing of extensive revisions for its review before the proxy statement is released. This practice, which is not expressly authorized by either the 1934 Act or the Commission's rules, results in a procedure analogous to that expressly provided for amendments to registration statements by $\$ 8(\mathrm{a})$ of the Securities Act of 1933. ch. $38,4^{8}$ Stat. 79 , as amended, ch. $686, \$ 301,54$ Stat. 857 (1940), 15 U.S.C. $\$ 77$ h(a) (I958). 
arise which cannot be resolved by discussions between the staff and counsel for the corporation, it is usually possible to secure prompt review of the matter by the Commission. ${ }^{10}$

The Commission does not exercise any judicial functions in supervising proxy solicitations. It does not itself have the power to halt proxy solicitations which in its view violate section $\mathrm{I}_{4}$ and must seek relief through judicial proceedings, if it believes that the law will be or has been violated. ${ }^{11}$ Furthermore, the fact that the staff or the Commission has passed proxy materials does not constitute a finding that the materials are in fact in compliance with the law, and material permitted by the Commission to be distributed can still be challenged by an injured party. ${ }^{12}$

\section{B. The Contested Meeting}

On the relatively rare occasion that a shareholder opposes management, the emphasis of the corporate meeting changes. Although the record of management's activities is still presented to the shareholders, the opposing groups become advocates, each pressing different conclusions which it argues can properly be drawn from the record. The annual meeting is no longer simply an occasion for the voting of proxies in ratification of management's control; it becomes instead the climactic event of a bitterly waged election campaign.

${ }^{10}$ See $I_{7}$ C.F.R. $\$ \$ 202 . I$ (d), 202.2 (Supp. 1963).

${ }^{11}$ Section $2 \mathrm{x}(\mathrm{e})$ of the Securities Exchange Act of 1934, 48 Stat. 900, as amended, ch. 804, 49 Stat. I921 (1936), I5 U.S.C. $\$ 78 \mathrm{u}(\mathrm{e})$ (1958), provides: "Whenever it shall appear to the Commission that any person is engaged or about to engage in any acts or practices which constitute or will constitute a violation of the provisions of this title, or of any rule or regulation thereunder, it may in its discretion bring an action in the proper district court of the United States, the District Court of the United States for the District of Columbia, or the United States courts of any Territory or other place subject to the jurisdiction of the United States, to enjoin such acts or practices, and upon a proper showing a permanent or temporary injunction or restraining order shall be granted without bond. The Commission may transmit such evidence as may be available concerning such acts or practices to the Attorney General, who may, in his discretion, institute the necessary criminal proceedings under this title." See also Securities Act of 1933 , ch. $38, \S 20$ (b), 48 Stat. 86, as amended, ch. 804, 49 Stat. 1921 (1936), 15 U.S.C. $\$ 77 \mathrm{t}(\mathrm{b})$ (1958); Public Utility Holding Company Act of 1935, ch. 637, $\$ 18(\mathrm{f})$, 49 Stat. 832 , as amended, ch. 804, 49 Stat. I92I (1936), I5 U.S.C. \$ 79r(f) (1958); Investment Company Act of $1940, \S 42(\mathrm{e}), 54$ Stat. 843 , I5 U.S.C. $\$ 80 a-4 I(e)(1958)$. For suggestions of other ways by which enforcement might be achieved in certain situations, see 2 Loss, op. cit. stupra note 8, at $93 x$.

${ }^{12}$ The Securities Exchange Act of 1934 expressly so provides, ch. $404, \$ 26,48$ Stat. 902, 15 U.S.C. $\$ 77 \mathrm{~W}$ (1958), reading: "No action or failure to act by the Commission or the Federal Reserve Board, in the administration of this title shall be construed to mean that the particular authority has in any way passed upon the merits of, or given approval to, any security or any transaction or transactions therein, nor shall such action or failure to act with regard to any statement or report filed with or examined by such authority pursuant to this title or rules, and regulations thereunder, be decmed a finding by such authority that such statement or report is true and accurate on its face or that it is not false or misleading. It shall be unlawful to make, or cause to be made, to any prospective purchaser or seller of a security any representation that any such action or failure to act by any such authority is to be so construed or has such effect." However, the action of the staff or the Commission is likely to have some effect if the question of compliance with the proxy rules should be litigated. In Union P.R.R. v. Chicago \& N.W.-Ry.2 226 F. Supp. 400, 406-07 (N.D. Ill. 1964), the court caid: .!'Where, as here, circumstances assure that agency consideration has been given to the merits of a question, the determinations and positions of the responsible authorities of the SEC carry significant weight and command deference in the courts." See-Peck v. Greyhound Corp., 97 F. Supp. 679 (S.D.N.X. I95I); EDwARD R. Aranow \& Herbert A. Einhorn, Proty Contests for Corporate Control 419-20 (1957). 
Proxy statements, which are usually not very exciting reading, become much more lively in style. Many other techniques, such as press releases, speeches, special messages to shareholders and advertisements, are used by the contenders to supplement the formal proxy materials. The subject matter of proxy solicitation is expanded beyond the limits of the record of the corporate entity into past and present affairs of the candidates; ${ }^{13}$ the contenders-like political candidates-present their platforms for the future management of the corporation.

The special rules promulgated in 1956 for use in proxy contests ${ }^{14}$ reflect the unusual nature of contests. When faced by a contest, the Commission and its staff take a somewhat different attitude and play a somewhat different role than they do where there is no contest:

When a proxy contest develops, however, the problems, the pressures, and the very atmosphere change. While the staff of the commission is scrupulously neutral, it does watch with great care and interest every move made by the parties. Proxy contests are vigorously, if not viciously, fought. They are frequently conducted on each side by a board of strategists which may include attorneys, accountants, advertising experts, public relations advisers as well as members of the opposing groups. Every legitimate, and occasionally not so legitimate, advantage is sought by each side. The role of the Commission approaches more nearly that of an umpire fixing the rules, detecting the infraction, and applying the remedy whether it be correction by retraction or explanation, or by process of the court. In most cases, the Commission seeks to obviate questionable statements by persuasion. The exigencies of tight time schedules and the risk of more

\footnotetext{
${ }^{13}$ In one recent proxy contest, the insurgents used a series of bulletins to stimulate stockholder
} interest and to obtain proxies. One bulletin carried the following two bold-faced headlines: "AGAIN - DOESN'T TELL THE WHOLE STORY"-"MANAGEMENT RETRACTS DESPERATION CLAIM." Another piece of proxy material sent to shareholders was entitled "WHAT [MANAGEMENT] DID NOT TELL YOU."

Towards the end of this proxy contest, "management grandly announced a common stock dividend of $5 \phi$ a share"-the company's first in over 32 years. The lead of the insurgents' reply bulletin read, "YOU CAN'T GET STOCKHOLDER'S SUPPORT FOR A NICKEL A SHARE!"

In another recent proxy contest, management countered reference to its "vested and selfish or conflicting interests" with the following:

"What about the $\$ 40,000$ fee [Insurgent's] brokerage firm collected from [another company] for the sale to [the Company]? [Insurgent] in his Proxy Statements gives his view of what he did to help put together the . . deal. We don't care WHAT he did! He had, as we see it, a selfish interest in purporting to act for [the Company] and at the same time collecting a $\$ 40,000$ fee from [the other company].

"And, let the stockholders ask Mr. [Insurgent]: What about your competing with [the Company] in the market for buying [Company] stock at a time when it was buying its own stock? We call this a clear conflict of interest.

"Mr. [Insurgent] your brokerage firm collected commissions during 1962 amounting to $\$ 7,349.90$ on purchases by [the Company] of its own stock. For part of 1962, you were buying [Company] stock -in competition with [the Company] in the market!

"So Mr. [Insurgent], we say to you: Let the stockholders look at your 'selfish interests' and 'conflicting interests' before you point the finger at others."

The insurgents countered with material which, if anything, was even more lively. In a news release prepared by the insurgents, the insurgent leader was quoted as follows:

"This is obviously a desperation attempt by high-salaried job holders with fat expense accounts to confuse their employers-the stockholders-and to perpetuate themselves in management.

"It is further a splashy display-using fire sale technique-of false charges warmed over and served up again despite previous public denial."

The lead on another insurgent release urged a state court to "CURB MANAGEMENT SPLURGE."

14 See Rule 14A-II, I7 C.F.R. \$240.I4a-II (Supp. I963). 
drastic action lend great weight to the suggestions of the staff. It is important to emphasize, however, that the staff is sensitive to the burden and responsibility this casts upon it. Moreover, where a genuine issue arises, counsel may ask for prompt consideration of the matter by the Commission. ${ }^{15}$

Notwithstanding this different atmosphere and the staff's role of neutrality, however, the basic administrative procedures remain the same as where there is no contest. Each side in a contested meeting must submit its proxy material to the Commission for review by the staff; the staff reviews the material filed and gives its comments to the party submitting the material. ${ }^{16}$ The existence of a contest does not alter the staff's position with respect to the accuracy required in statements of pure fact. However, greater freedom with respect to interpretative material, or the stating of opinions, ${ }^{1 \tau}$ is usually countenanced by the staff when there is a contest. This result can be explained on the ground that interpretations and opinions which will be answered need not be held to as strict a standard as similar statements which will be left unanswered.

It is very difficult to state precisely the scope of freedom countenanced when there is a contest. The few decisions in this area are not consistent. ${ }^{18}$ The present position of the Commission and the staff might be said, on the basis of recent dis-

${ }^{15}$ Cohen, supra note 8 , at ro2-03.

${ }^{10}$ Press releases and radio or television scripts, although constituting proxy material, do not have to be filed prior to use or publication, although definitive copies of such matcrial must be filed not later than the date of use or publication. Rule I $_{4 a-6(g)}$, I7 C.F.R. $\$ 240.14 a-6(\mathrm{~g})$ (Supp. 1963).

${ }^{17}$ The staff insists that it be supplied with extensive data supporting the opinions and interpretations expressed in proxy statements for contested meetings. This data may be supplied by affidavits or interviews and, in some instances, the staff will conduct its own investigation.

In one proxy contest, management filed as back-up material for its proposed initial distribution a long memorandum of facts with twelve documents as exhibits and in addition an agrcement, an affidavit, two memoranda. and a letter. Later, upon the staff's request for back-up for the assertion that there had been frequent shifts in the management of another company controlled by the insurgents, management filed first a table showing the actual management changes in the other company over the period of years in question and then a memorandum outlining the circumstances of each change and the source of information as to the change. When management wanted to quote a statement made in court by a lawyer for the opposition, the staff asked that the complete transeript of the argument be filed. Ultimately, the staff was satisfied by the transcript of the part of the argument involved and assurances as to the circumstances involved from counsel for management. It should be remembered that backup material must often be assembled and filed in a matter of days and sometimes hours.

${ }^{18}$ In Securities and Exchange Commission v. Okin, 48 F. Supp. 928, 930 (S.D.N.Y.), madified and $a f f^{\prime} d$, I37 F.2d 862 (2d Cir. 1943), Judge Simon Rifkind said: "[I]t secms to me that the letter must be read with some regard to the fact that it belongs to the class of contentious writings and that the art of advocacy has always taken some liberties with the 'whole truth.' Furthermore, it is a letter by a minority stockholder in opposition to the management. That factor does not constitute a license to lie but it does afford the reasonable expectation that understatement or exaggeration will be answered-a condition not always to be anticipated when the communication reviewed issues from the management."

Judge Charles E. Clark, however, appears to reflect a slightly different attitude in Securites and Exchange Commission v. May, 229 F.2d I23, I24 (2d Cir. 1956): "Appellants' fundamental complaint appears to be that stockholder disputes should be viewed in the eyes of the law just as are political contests, with each side free to hurl charges with comparative unrestraint, the assumption being that the opposing side is then at liberty to refute and thus effectively deflate the 'campaign oratory' of its adversary. Such, however, was not the policy of Congress as enacted in the Securities Exchange Act. There Congress has clearly entrusted to the Commission the duty of protecting the investing public against misleading statements made in the course of a struggle for corporate control." 
cussions and experience, to be that each side will be held to the same standard of truth and required to disclose all the facts within its knowledge. The Commission and the staff will take into account that both sides may not have equal access to the facts and that, as a consequence, one side may have a greater ability than the other to present all the facts. Thus, when a matter in dispute is subject to some doubt, a full disclosure of all the facts known by the side speaking to the issue will be required, but it will be left to the opposition to bring out any further facts of which it may have knowledge.

The Commission's and the staff's handling of proxy material in contested situations reflects a desire to permit each party to present its case to the corporate electorate-rather than to stifle advocacy-and also an attitude that somewhat greater freedom is proper when statements will be answered by an opposition. It may also be affected by the Commission's desire that the staff remain neutral insofar as possible. In terms of the practicality of the situation, this approach seems, on the whole, to be a realistic solution and to afford both protection to shareholders and an opportunity for the opposing sides to engage in the art of advocacy.

II

\section{The Evolution of the Proxy Rules}

Looking back over the history of the proxy rules, one cannot help but be struck by the parallel between their development and that of the common law. Mr. Justice Holmes, writing on the common law, remarked that "The life of the law has not been logic: it has been experience."19 In some ways this observation is applicable to the development of the proxy rules. Those rules have been molded, at least in substantial part, by the experience of the Commission and its staff, rather than devised as an a priori logical system. The continuing dialogue between proxy solicitors and the Commission and its staff, with an occasional intervention by the courts, has led to the development of a more and more complex set of rules designed to deal specifically with problems emerging from past experience.

In his $x 962$ Holmes Lectures at the Harvard Law School, Judge Henry J. Friendly argued that whenever Congress grants power to an agency in broad and general terms, "it is imperative that steps be taken over the years to define and clarify it-canalize the broad stream into a number of narrower ones."20 This thesis was propounded with respect to the adjudicatory functions of administrative agencies, but it seems to reflect a more general goal-that areas of legal uncertainty should be narrowed as they become important to society-and is equally applicable to the rule-making functions of the administrative agencies.

This process of definition and clarification should not, however, lead to the loss of one of the important advantages of administrative agencies: their flexibility

${ }^{10}$ Oliver Wendell holmes, The Common Law i (i881).

${ }^{\circ}$ Friendly, The Federal Administrative Agencies: The Need for Better Definiton of Standards, 75 HARv. L. REv. 863, 874 (1962). 
in approaching problems. Through its pragmatic approach to the administration of the proxy rules, the Commission has been able to accommodate the process of definition and clarification with the need to maintain sufficient flexibility to fit the rules to new problems created by changes in the relationship between the corporation and its shareholders.

\section{A. Towards Greater Precision}

Congress' mandate to the SEC with respect to the proxy rules was about as broadly and generally phrased as could be imagined. The Commission was instructed to promulgate rules which it deemed to be "necessary or appropriate in the public interest or for the protection of investors," and its first rules, adopted on September II, 1935, were really nothing more than a set of principles which permitted the Commission to control the most blatant abuses while studying further the needs and requirements of the problem which Congress had given to it. ${ }^{21}$ Nevertheless, the original rules followed the general approach which has been continued since by requiring (a) a "brief description" of the issues to be considered at the meeting, together with the action proposed to be taken by the holder of the proxy, (b) the mailing of other stockholder material by management, although at the stockholder's expense, and (c) a general prohibition against materially false or misleading statements.

The Commission used the experience gained under the holding action of the I935 rules to formulate a comprehensive set of rules promulgated in $1938 .{ }^{22}$ These rules, denominated Regulation X-14 (now known as Regulation 14 ), were cast in the form which is familiar to practitioners today. They imposed the requirement of a proxy statement and specified that the proxy itself must be one in which the shareholder was entitled to vote either yes or no on each proposition other than elections to office.

Two years later, Regulation X-I4 was amended in a number of respects, the most significant amendment being the requirement that preliminary proxy material be filed ten days before its distribution. ${ }^{23}$ This amendment was one of particular

${ }^{21}$ SEC Securities Exchange Act Release No. 378 (Class A), Sept. 24, 1935 (Regulation LA); sec Security and Exchange Commission Proxy Rules, Hearings on H.R. 1493, H.R. 1821, and H.R. 2019 Before the House Committee on Interstate and Foreign Commerce, 78th Cong., rst Sess., pt. I, I4-15 (1943) (testimony of Chairman Purcell) [hereinafter cited as 1943 Hearings]: "Now, of course, the Commission knew that these rules would not give adequate information to stockholders. It adopted the rules merely as a means of finding out what types of information should be required in complying with the congressional direction and also in the interim to prohibit false information from being circulated to stockholders. It anticipated that later it would be able to adopt affirmative rules of the type that Congress had in mind."

${ }^{22}$ Amended Proxy Rules, SEC Securities Exchange Act Release No. 1823, 3 Fed. Reg. 1991 (1938).

${ }^{23}$ Amendment of Regulation X-14, SEC Securities Exchange Act Release No. 2376, 5 Fed. Reg. 174 (1940). The Commission's decision to require pre-filing of proxy matcrials may have been based not only on its experience with proxy materials but also on its experience with registration statements filed under the Securities Act of 1933. Registration statements usually must be amended to comply with the staff's comments before they are permitted to become effective. For the five and one-half years ended December 31 , I952, less than $4 \%$ of the registration statements filed were permitted to become 
significance in the development of the proxy rules because it afforded the staff of the Commission an opportunity to review proxy material before such material was transmitted to shareholders and thus to make known its position to those soliciting proxies at a time when changes in the proxy statement could be made. Viewed in retrospect, this was an essential step in the developing and expanding role which the staff was to play with respect to the substance of proxy statements. ${ }^{24}$ The 1940 amendment also imposed, for the first time, a requirement that a proxy statement include "any matters which the persons making the solicitations are informed other persons intend to present for action at such meeting." 25

By changes issued in late 1942 , to take effect on January $\mathrm{r}, 1943$, the Commission completely revised and rewrote Regulation X-I4. The new rules included substantive provisions requiring the disclosure of management salaries and corporate dealings with officers and the inclusion of a roo-word statement submitted by a shareholder in favor of a proposal made by him. This amendment also required for the first time that the corporation's annual report precede or accompany the proxy statement; it did not require, however, that the annual report be subject to all of the provisions contained in Regulation X-r4 applicable to proxy statements. ${ }^{26}$

In 1947 Regulation X-I4 was again revised and restated. In addition to rearranging the order of the rules, the 1947 revision required the filing of instructions given to people making personal solicitations for proxies, permitted management to furnish opposition proxy solicitors a list of shareholders in lieu of mailing the opposition's material, and stated explicitly management's right to include in its materials a statement disagreeing with any shareholder proposal required by the rules to be included in management's solicitation. ${ }^{27}$

The provisions of Regulation X-I4a-8, relating to the inclusion of shareholder proposals and management's proxies, were further amended in I948. Under the revised rule, management could omit a shareholder's proposal if proposed primarily "for the purpose of enforcing a personal claim or of redressing a personal grievance" or if substantially the same proposal had been submitted at the previous annual meeting and had received less than three per cent of the votes cast on the proposal. ${ }^{28}$

cffcctive without amendment. I Loss, op. cit. supra note 8, at 273 n.23. Thus, without the pre-filing procedure of the 1933 Act, it seems likely that the Commission would have had to resort more frequently to stop-onder proceedings to secure compliance with the disclosure requirements applicable to registration statements.

${ }^{26}$ For a discussion of the 1940 amendments, see Bernstein \& Fischer, The Regulation of Proxies: Some Reflections on Corporate Democracy, 7 U. CHI. L. Rev. 226 (1940).

${ }^{25}$ Rule X-I 4a-8(i), Amendment of Regulation X-r4, SEC Securities Exchange Act Release No. 2376, 5 Fed. Reg. r75 (I940).

${ }^{\circ}$ Solicitation of Proxies under the Act, SEC Securities Exchange Act Release No. 3347, 7 Fed. Reg. 10655 (1942).

${ }^{87}$ Solicitations of Proxies, SEC Securities Exchange Act Release No. 4037, 12 Fed. Reg. 8768 (1947); see Note, 2 T TEMP. L.Q. 406 (I948).

${ }^{28}$ At the same time, the Commission made mandatory (a) a statement as to whether the proxy was being solicited on behalf of management, and (b) an indication how, within reasonable limits, the proxies would be voted. Solicitation of Proxies, SEC Securities Exchange Act Release No. 4185, 13 Fed. Reg. 6678 (1948). 
In 1952 Regulation X-I4 was again revised. In its release announcing the revisions, the Commission characterized the following as major changes: the inclusion of the requirement that the proxy be dated, permission for management to exclude shareholder proposals "submitted primarily for the purpose of promoting general economic, political, racial, religious, social or similar causes," additional rules on the disclosure of salaries and remuneration, and, when a bonus plan is being submitted to the shareholders, the requirement that previous plans of a similar nature for directors and officers be disclosed. ${ }^{29}$

The proxy rules were again amended in r954. These amendments, relating principally to shareholder proposals, placed the burden of proof on management, when it desired to omit a shareholder proposal because it was not proper under state law, to establish the validity of its view of state law and required management to notify the SEC of its intent to omit a shareholder proposal twenty days prior to the filing of its preliminary proxy materials. The I954 amendments also required, as a-condition to management's duty to include shareholder proposals, that such a proposal, if previously submitted, have obtained a specified percentage of the votes cast on the previous submission, the percentage rising with the number of submissions during the preceding five years. ${ }^{30}$

The latest significant revision of Regulation I4 occurred in 1956. "The principal purpose of the amendments... [was] to clarify the applicability of Regulation X-14 to proxy contests with respect to the election or removal of directors. Accordingly, the rules ... [were] expanded to spell out more specifically the procedure to be followed and the information to be given in the case of such contests. ${ }^{131}$ The 1956 revision established more comprehensive rules concerning solicitation, making it clear that any communication with shareholders which was intended to be followed by a solicitation constituted the beginning of that solicitation. It also expanded the definition of participants in proxy contests, required the submission of a schedule (Schedule ${ }_{14} \mathrm{~B}$ ) giving information and data concerning the participants' background, subjected to the rules applicable to proxy statements any annual report used to attack or comment on an opposition solicitation and reprints or republications used in a proxy contest, and provided that press statements or other oral communications taking place during the proxy contest must be filed with the Commission immediately after their release.

${ }^{29}$ Solicitation of Proxies, SEC Securities Exchange Act Release No. 4775, I7 Fcd. Reg. II 431 (I952).

${ }^{30}$ Solicitation of Proxies, SEC Securities Exchange Act Release No. 4979, r9 Fed. Reg. 246 (I954). If a shareholder proposal was submitted more than once during a five-year period, management, on a resubmission, was required, under the new rules, to include in its proxy statement only proposals which had received, on the last vote, $3 \%$ of the total vote if submitted once in the five-ycar period, $6 \%$ if twice, and 10\% if three times or more. Rule I4a-8, I7 C.F.R. $\$ 240.14 a-8$ (Supp. 1963).

${ }^{31}$ Amendments to Proxy Rules, SEC Securities Exchange Act Release No. 5276, 21 Fed. Reg. 577 (1956). See generally, Orrick, The Revised Proxy Rules of the Securities and Exchange Commission, Bus. Law., April I956, pp. 32, 33; Stock Market Study (Corporate Proxy Contests), Hearings on S. 879 Before a Subcommittee of the Senate Committee on Bonking and Cturrency, 84th Cong., 1st Sess., pt. 3, at I692-98 (1956) [hereinafter cited as Stock Market Study]. 
The 1956 revision has now been in effect some eight years. Both the SEC staff and practicing lawyers have worked with it, and many proxy contests have been conducted under it. Although it is much more detailed than the original rules of r935, further evolution will undoubtedly lead at some time to changes in the present version.

\section{B. The Role of Experience}

Because the procedure through which the Commission administers the proxy rules is principally informal and private, it is difficult to gather sufficient representative examples to demonstrate the role which the experience of the Commission and its staff has played in the evolution of the proxy rules. ${ }^{32}$ Our conclusion that the Commission's development of the proxy rules has had a strong empirical basis could be fully confirmed only by a study of the Commission's private files.

One example of the part played by experience is the expansion of the rule prohibiting false and misleading statements. From the beginning the proxy rules have contained a prohibition similar to that presently contained in Rule r4a-9:

No solicitation subject to this regulation shall be made by means of any proxy statement ... containing any statement which, at the time and in the light of the circumstances under which it is made, is false or misleading with respect to any material fact, or which omits to state any material fact necessary in order to make the statements therein not false or misleading. . . . ${ }^{33}$

\footnotetext{
${ }^{39}$ Sometimes the Commission, rather than going directly from experience to an amendment of the existing rule or the promulgation of a new rule, publishes answers to inquiries relating to proxy solicitation or issues interpretative opinions as a means through which interested persons can be informed of its position. An example of this procedure occurred within the past few months. In the fall of 1963 , the Commission decided that sending a brokerage report which assessed the relative merits of opposing bids by the Chicago \& Northwestern Railroad and the Union Pacific Railroad for control of the Chicago, Rock Island \& Pacific Railroad to stockholders without a request for such a report constituted solicitation within" the scope of $\$ I_{4}$. Accordingly, the Office of the General Counsel warned the New York Stock Exchange and the brokerage houses concerned that "transmission of proxy material to stockholders, whose stock is held in the street name . . may constitute a solicitation." This action was followed by the Commission's release on January 7, I964, of an opinion of its General Counsel dealing with this subject. Broker-Dealer Participation in Proxy Solicitations, SEC Securities Exchange Act Release No. 7208, Jan. 7, 1964. It would not be surprising if the Commission were at a later date to propose a rule dealing with this problem.

${ }^{33}$ I 7 C.F.R. $\$ 240.14 a-9$ (Supp. I963). In several of its annual reports the Commission has provided examples of cases in which it felt that additional disclosure was required to provide complete information or to avoid being misleading. A management solicitation seeking proxies for a by-law amendment which would make $33^{T} \% 3 \%$ of the stock a quorum at any meeting of stockholders was required to disclose that the corporation's president personally owned $38 \%$ of the outstanding stock. The plan was then dropped "as not being feasible." 5 SEC ANN. REP. 6r (I939). The Commission objected to a proxy statement which failed to disclose that the president and another candidate for election as a director were defendants in lawsuits based on alleged fraudulent transactions arising out of their corporate stewardship. Ibid. In soliciting proxies approving the issuance of preferred stock, management was required to disclose plans for a large underwriting fee to the underwriter, a corporation owned by the soliciting corporation's president. On resolicitation, management did not seek approval of the stock issue. 6 SEC ANN. REP. II4 (I940). In a number of cases involving recapitalizations, the Commission demanded additional disclosure, and these demands frequently led to revisions of the plans. In one case, a cement company, which wanted its preferred shareholders to yield substantial rights, failed to disclose that the preferred dividends had been earned although not declared in many years and that management had used earnings to buy up preferred stock on the market. The plan was subsequently modified. I3 SEC ANN. REP. 42-43 (I947). For other examples of
} 
Out of the experience which it had gathered since 1935, the Commission, in its I956 amendments to the proxy rules, added a note to the rule dealing with false or misleading statements which gave four examples of such statements: ${ }^{34}$

(a) Predictions as to specific future market values, earnings, or dividends.

(b) Material which directly or indirectly impugns character, integrity or personal reputation, or directly or indirectly makes charges concerning improper, illegal or immoral conduct of associations, without factual foundation.

(c) Failure to so identify a proxy statement, form of proxy and other soliciting material as to clearly distinguish it from the soliciting material of any other person or persons soliciting for the same meeting or subject matter.

(d) Claims made prior to a meeting regarding the results of a solicitation.

The examples set forth in the note are general statements of what must have been recurrent individual situations presented to the staff during the two decades of experience which preceded the $195^{6}$ amendments.

Another example of the tendency towards greater definition is the Commission's handling of the problem of the inclusion in management proxy statements of shareholder proposals to be presented to the meeting for consideration, when management has been informed that such a proposal will be presented. Beginning in 1938, the Commission had ruled in many individual instances that it was misleading for management to omit such information from its proxy statement. ${ }^{35}$ In

what has been found by the Commission's staff to be false or misleading statements, sec Aranow \& EinhorN, op. cit. supra note 12 , at 132 .

34 Prior to this revision, Chairman Armstrong, in an address, on February 9, 1955, to the Chicugo Chapter of the American Society of Corporate Secretaries (reprinted in Stock Market Study $1560-76$ ), had outlined the following seven general categories of misleading statements:

" $x$. Distortion of business or financial facts for the purposes of creating inferences or impressions favorably [sic] to the contestants which are unwarranted by the underlying facts.

"2. Expressions of opinions or conclusions concerning the operations of the company not supported by, or contrary to, the known facts or the facts asserted to substantiate or establish a basis for the statements made.

"3. The use out of context of statements made by courts, congressional committees, and administrative agencies and similar bodies or reference to indictments or unproven charges or similar matters under circumstances which imply or infer conviction or guilt which has not in fact becn established.

"4. The expressions as fact of that which should be clearly identified as opinion.

"5. Resort is had, without supporting facts, to personal attack by association with criminals, Communists, or references to illegal acts or events generally regarded as contrary to the public interest, or by the use of reprints or extracts from newspapers and periodicals of a generally derogatory nature.

"6. The use of libelous, defamatory, scurrilous, or similar material.

"7. Claims, promises, or projections as to future earnings, dividends, sales, and increases in value of assets or stock based on mere conjecture or distortion, or reconstruction of past operating results of the company without regard to generally accepted accounting, statistical, or financial principles."

It is interesting to compare these seven categories with the four categories appended to the rules. Although the two groups overlap, the published examples are more specific; indecd some of the catcgories mentioned by Armstrong in his speech, such as number 4 (expressions of fact which should be labeled opinions) express only a general approach to the problem of misleading statements. Chairman Armstrong appears to have used this informal platform to elaborate the rules in a manner which could not be done through the more formal rule-making procedure. For criticism of an abuse by the Federal Communications Commission of such informal means of expressing agency views, sce Kennetri C. Duvis, Administrattre LAW 54.03 (I958).

${ }^{85}$ See 5 SEC ANN. REP. 62 (1939) (misleading for management to omit shareholder proposals to change place of annual meeting and to elect auditors). 
x940 these ad hoc determinations were incorporated into the proxy rules, and in 1942 the Commission added the requirement that management not only set forth the shareholder's proposal but also include, if it were supplied, a roo-word statement by the shareholder in support of the proposal. ${ }^{36}$

The Commission's process of constant refinement is further illustrated, in the same area of shareholder proposals, by the evolution of the restriction imposed on the resubmission of shareholder proposals, from the initial absence of any restriction ${ }^{37}$ through the imposition of a requirement that the proposal have obtained three per cent of the vote at its previous submission ${ }^{38}$ to the present $3^{-6}$-ro rule. ${ }^{38}$

A third example is the Commission's treatment of the relation of annual reports to proxy solicitation. Prior to I942, the proxy rules made no mention of the annual report. The 1942 revisions mentioned the annual report for the first time and required that it precede or accompany the proxy statement. This requirement was imposed because experience had shown that some corporations had taken advantage of the absence of any affirmative requirement in the proxy rules governing mailing of annual reports to send the annual report to shareholders after the annual meeting. Since the proxy rules did not then (and, except when certain special matters are to be presented to the stockholders, do not now) contain affirmative requirements relating to the disclosure of profits, earnings, and other financial data, shareholders in corporations which did not provide an annual report with the proxy statement were being asked to re-elect management without being apprised of management's financial record during the preceding year-a considerable disadvantage if the corporation had experienced financial adversity. As Chairman Purcell stated in the I943 hearings:

That, of course, resulted in obtaining the re-election of the board of directors without telling stockholders how their corporations had been operated during the past year. ${ }^{40}$

At the same time that it required the annual reports to precede or accompany the proxy statement, the Commission rejected a proposal that the proxy rules be made applicable in their entirety to the annual report. ${ }^{41}$ By 1956 , however, the Commission had found that in some instances managements involved in a proxy contest were using the annual report as a means of attacking the opposition without

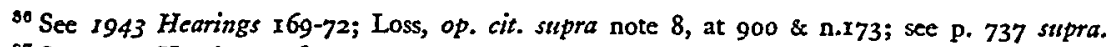

${ }^{37}$ See 1943 Hearings 138.

${ }^{38}$ See p. 737 supra.

30 See note 30 supra.

10 r943 Hearings $167-68$.

"1 1943 Hearings 18-20; see Stock Market Study 1556: "Many companies complained at that time [1942] that if the annual report to shareholders must be 'filed' with the Commission and thercfore subjected to the civil liability provisions of section 18 , the effect would be to place severe limitations upon the freedom of communication and comment to shareholders concerning corporate affairs. The Commission at that time believed it would be in the public interest to encourage, rather than to limit, the dissemination of information to security holders and that, if fear of civil suits might have an adverse effect in this respect, it might be better to require delivery of the report but to free it from the provisions of section $18 . "$ 
being subject to the restrictions of the proxy rules. ${ }^{42}$ Consequently, when the Commission issued its special rules applicable to proxy contests in 1956, it required the filing as proxy material "of any portion of the annual report ... which comments upon or refers to any solicitation subject to this rule, or to any participant in any such solicitation, other than the solicitation by the management ...." ${ }^{* 3}$ In 1963 the Commission issued an interpretative ruling which further refined the requirements of the proxy rules applicable to annual reports. This ruling indicates that the existing rules require the inclusion in a corporation's annual report of financial statements of any significant subsidiary and that the annual report be mailed by the same class of mail as the proxy statement. ${ }^{44}$

\section{The Effect of Procedure Upon Substance}

In retrospect it seems clear that the Commission's decision in 1940 to require that proxy materials be filed with the Commission sufficiently in advance of mailing to permit comments by the staff was of critical importance to the development of the substance of the present proxy rules. ${ }^{45}$ Prior to 1940, the staff of the Commission was prepared to make informal comments on proxy materials before they were transmitted, and some corporations took advantage of this procedure. The Com: mission, however, felt that it was handicapped in dealing with questionable proxy materials because such materials often were not submitted before transmittal.

It is interesting to speculate on the course which the evolution of the Commission's procedures might have taken had the Commission not required such prefiling. Since, in that event, the Commission would have had no way of making its views known prior to transmittal and, since the Securities Exchange Act did not vest in the Commission effective administrative sanctions to enforce the proxy' rules, enforcement would have depended to a far greater extent on the courts thán has been the case. It also seems likely that private initiative in instituting litigation would have played a far greater part in the development of the proxy rules;" for the limited resources of the Commission would necessarily have restricted its ability to initiate and prosecute litigation.

Whether rules developed by the courts on the basis of opportunities afforded by the initiative of private litigants would have been as satisfactory as those developed

"2 Armstrong, The Role of the Securities and Exchange Commission in Proxy Contests of. Listed Companies, Bus. Law., Nov. 1955, pp. Iro, I2I.

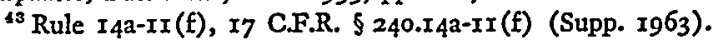

"Proxy Rules-Interpretation, SEC Securities Exchange Act Release No. 7078, May I5, 1963. On May 26, I964, the Commission amended Rule $14 \mathrm{a}-3$ to require that the annual report include consolidated financial statements, if necessary to reflect adequately the financial position and results of operations of the corporation and its subsidiaries. The amendment also requires that financial statements in' annual reports explain any material differences between such statements and financial statements filed with the Commisoion and, with some exceptions, that financial statements in annual reports be certified by independent'public accountants. SEC Securities Exchange Act Release No. 7324, May 26, 1964. $\quad: \quad \therefore \quad \therefore$

${ }^{45}$ In holding that failure to file solicitation material was a material violation of the proxy.rules;ad. federal court recently described the "opportunity to consider-the solicitation material" as "thdifirst linic of enforcement." Union P.R.R. v. Chicago \& N.W. Ry., supra note 12, at 408. 
by the Commission through its informal administration is doubtful. In the case of non-contested meetings, it seems unlikely that the results would have been as satisfactory. There would probably have been a tendency either for the proxy rules in this area to have been ignored because of shareholder lack of information and incentive or for the Commission to have over-reacted by promulgating a mass of detailed rules. Such rules generally serve little practical purpose and may well hinder the functioning of the corporate meeting by requiring overly elaborate and detailed proxy statements. They immerse the significant in a mass of detail and, although they may insure that individual parts of a proxy statement are not misleading, they may at the same time render the statement viewed as a totality either incomprehensible or misleading by prohibiting as improper information required under particular circumstances to understand the whole picture. Through its informal administration of the proxy rules, the Commission has managed to-steer a reasonably satisfactory course between these two dangers.

In the case of the contested meeting, there is reasonable likelihood that many private litigants would have brought court proceedings in the absence of administrative review or extremely elaborate rules governing proxy statements. Such rules are probably even more undesirable in the case of contested meetings than they are in the case of uncontested meetings, because no set of rules, however elaborate, could adequately anticipate the almost endless variety of issues presented by contested meetings. Nor would litigation have been an efficient way of elaborating the proxy rules in this area, for it might well have defeated the very interest which the rules are designed to serve by hopelessly confusing corporate meetings through suspensions of solicitations, court orders requiring resolicitations and repeated postponements.

In any event, it is our view that in the absence of one of the principal advantages of the present system of informal administration of the proxy rules- the private and off-the-record exchange between the staff and the solicitor with the accompanying effort to persuade outside of an adversary context-the proxy rules today would be more complex, their substance would be quite different and they would be less responsive to the needs of the situation. The raw material of the staff's experience, properly evaluated and used by the Commission, is a far more satisfactory basis on which to develop and refine the proxy rules than court decisions or the Commission's a priori judgments.

\section{III}

\section{Enforcement of the Proxy Rules}

As has been pointed out earlier in this paper, the Commission can formally enforce compliance with the proxy rules only by obtaining an injunction. ${ }^{4}$. When the Commission seeks an injunction, it may, depending on the circumstances, attempt

\footnotetext{
${ }^{10}$ See note II supra.
} 
to enjoin the distribution of the offending material, the voting of proxies obtained through use of the offending material, or the corporate meeting itself.

The Commission, however, has only infrequently resorted to court action to enforce its position that proxy materials did not comply with its rules. ${ }^{47}$ In situations where there is a contest for corporate control, the Commission has expressly stated that it is reluctant to seek injunctive relief. In I955 Chairman Armstrong of the Commission testified:

As a matter of policy the Commission has been reluctant to initiate litigation during a proxy fight in the absence of a material violation of the rules. This position springs in part from an unwillingness to inject the Commission into an election campaign unless a material violation of the rules is involved. Finally, the Commission is unwilling to take action which may result in disfranchisement of security holders. ${ }^{48}$

The Commission has enforced compliance with the proxy rules very largely through exercise of what Professor Kenneth C. Davis has called the "supervising power," which he describes as:

... the power of an administrative agency to coerce a regulated party by methods other than adjudication or rule making. It is a concomitant of, an outgrowth from, and a substitute for the prosecuting power. In some of the most effective regulatory agencies, perhaps nine tenths or more of the desired results are produced through exertion of the supervising power. ${ }^{48}$

\section{A. The Leverage of the Supervising Power}

There are several reasons why the supervising power can be used so effectively in enforcement of the proxy rules. The relationship between the staff and a corporation with respect to proxy materials is continuing. ${ }^{50}$ The problem of clearing proxy materials is a recurrent one. In the ordinary course of corporate affairs, such materials must be cleared at least annually. In the exceptional case in which a contest develops, there may be many mailings for the contested meeting, each of which must be cleared in a matter of days, if the material is to be useful in the contest. In the context of this relation, the staff can give effect, in its consideration of subsequent issues, to its dissatisfaction with any past failures or reluctance to comply with its interpretations of the proxy rules. Consequently, the staff's suggestions are likely to be accepted in many situations in which there might be a substantial question whether the Commission could prevail, if the matter were litigated.

Furthermore, in the case of proxy contests, the threat to institute court proceedings increases the leverage of the supervising power. Whether or not the Commis-

${ }^{47}$ From 1934 to 1955 the SEC appeared as a party litigant in seventeen cases involving the proxy rules and as an amicus curiae in eleven cases, Stock Market Study 1543-44. See Armstrong, The Role of the Securities and Exchange Commission in Proxy Contests of Listed Companics, Bus. Law., Nov. 1955, pp. II0, II6.

"Stock Market Siudy 1552.

10 I Kenneth C. Davis, Administrative Law $\$ 4.01$ (1958).

${ }^{80}$ Another example of such a relationship is that involved in the "evergreen" prospectus of mutual funds. 
sion would be successful in an effort to secure an injunction, sufficient adverse publicity might well be generated by allegations that one side in the contest had violated the proxy rules to diminish substantially the likelihood of that party's ultimate success in the contest. Therefore, although in proxy contests there is often some "brinkmanship" in which one side or the other ignores what it considers to be relatively minor comments of the staff, the risk of damage to its position from a court proceeding instituted by the Commission, even if the Commission is ultimately unsuccessful, is such that any significant comments of the staff will generally be accepted.

\section{B. The Danger to Be Avoided}

Whenever any institution has the power to regulate an important phase of the economy through a broad and ill-defined grant of power and by use of informal procedures, there are opportunities for abuse and, historically, a certain amount of abuse develops. This is a reflection of the general imperfection of human institutions and the fact that no means can be devised to create the power to prevent evasion and, at the same time, insure absence of abuse and overreaching.

The exercise of the supervising power over proxy solicitation is particularly subject to the possibility of abuse. It is wielded by the Commission and the staff in a context which deprives the regulated party of procedural safeguards and, in most instances, of the opportunity for judicial review. Thus, as James M. Landis has said, "Checks upon arbitrariness here must lie within the administrative itself."

Generally speaking, it is our view that the proxy rules have been impartially and reasonably well administered by the Commission and its staff, and it is not the purpose of this paper to suggest otherwise. Indeed, we believe that the history of the administration of the proxy rules is one to which the Commission can point with pride in terms of achieving a congressional objective. However, it may be helpful to articulate some of the considerations which the Commission and its staff should, in our view, keep in mind in administering the proxy rules in the interest of fairness and the safeguarding of the advantages of informal administration. ${ }^{52}$

One such consideration is the dual positions of the Commission and the staff as formulators and enforcers of policy. Having created the substance of the law, they then decide in specific cases and in private discussions whether there has been compliance. Their decisions, although they can be ignored by the proxy solicitor, are likely to be of considerable significance if the question is litigated. ${ }^{53}$ A second relevant consideration is the relatively greater scope that is proper for the Commission and the staff in their roles as formulators of rules, a procedure involving public notice and compliance with the requirements of the Administrative Pro-

\footnotetext{
di Jaries M. Landis, The Administrative Process 1 io (1938).

${ }^{29}$ Professor Davis has discussed the exercise of the supervising power by the Commission in connection with its supervision of registration and acceleration. He also gives other examples of its use. See I Davis, op. cit. supra note 49, $\$ \$ 4.0 \mathrm{I}-4.12$.

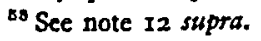


cedure Act, ${ }^{54}$ compared with their scope in enforcing the proxy rules. In their roles as formulators of policy, it may be quite proper for them to advocate specific individual views as to what is desirable or undesirable, but in their enforcement roles they should, for the most part, confine themselves to enforcement of the then existing proxy rules in a fair, even-handed manner.

These two basic considerations lead to certain general principles which, in our view, should govern the enforcement of the proxy rules. First, the Commission and the staff should not use leverage afforded by time pressures or the continuing relationship between them and the proxy solicitor to impose requirements which have been rejected by the Commission or the courts or which are inconsistent with established positions of the Commission or the courts. The broad reach of the concept of "misleading" should not be used by the staff to require disclosures which in a ruling-making proceeding the Commission has decided are not required.

Second, the Commission and the stafi should recognize the practicalities of specific situations. They should not impose new disclosure requirements, not specified in the rules and not called for in similar situations in the past, where the assembly of the required data would be costly and difficult. And, third, the Commission and the staff should remember that their goal should not be that of advocate or rule-maker when they are concerned with the informal review of proxy materials, and they should approach their task with as judicious a state of mind as possible.

In stating the considerations and principles discussed above, we do not mean to suggest that there have been substantial departures from them in the administration of the proxy rules. However, it is instructive to consider an interesting case history which may illustrate some of the points discussed above. In the early xg6os a spate of stockholder derivative actions were brought against directors of open-end mutual funds, principally challenging management fees. Many of these cases were settled. After the settlements had been approved by the courts upon notice to all shareholders and hearings on the fairness of the settlements, the new advisory agreements resulting from the settlements were submitted to the shareholders of the mutual funds for approval as required by section 15 of the Investment Company Act of 1940 .

The first proxy statements presenting such new contracts to fund shareholders were processed by the staff with only minor comments. Later proxy statements, however, had quite a different experience. The staff insisted, with the approval of the Commission, upon the inclusion of detailed financial information concerning the management company which.the Commission's rules did not require for proxy statements seeking the approval of investment advisory contracts. ${ }^{56}$ The processing

${ }^{54}$ Ch. $324, \$ 4,60$ Stat. 238 (1946), 5 U.S.C. $\$ 1003$ ( $(958)$ ).

${ }^{55}$ The solicitation of investment company proxies is subject not only to Regulation . 14: but also to specific rules promulgated by the Commission under the Investment Company Act of x949s see Rule 20a, 17 C.F.R. $\$ 270.20 a-1-.20 a-3$ (Cum. Supp. I962). 
of these later proxy statements involved in some instances many months and produced proxy statements of extreme length and complexity. ${ }^{56}$

It would seem that with respect to these later proxy statements the considerations and principles set forth above were not adhered to. On January 7 , 1960, the Commission had issued a proposed revision of Rule $202^{57}$ governing proxy solicitations by investment companies. This notice contained proposed Rule 20a-2, which required that whenever directors of an investment company were to be elected or an investment advisory contract submitted for shareholder approval, a balance sheet of the investment advisor as of the end of its last fiscal year and "its profit and loss statement for the last fiscal year (which shall show the principal sources of its gross income and major items of expense) and an analysis of surplus" must be included in the proxy statement. ${ }^{58}$

On February 26, Ig60, the Commission adopted a revision of proxy rule 20 . This revision did not include the language quoted above which had been proposed for inclusion in Rule 20a-2.59 Nevertheless, the proxy rules were construed to require the inclusion of profit and loss information relating to the advisory company, even more detailed than that proposed and rejected by the Commission, in later proxy statements submitting advisory contracts after settlement of stockholder litigation. This caused considerable expense to many of the mutual funds and management companies involved-expense which was inherent in the demand for

${ }^{50}$ In one instance of which we are aware, two funds under the same management submitted substantially identical new management agreements to their shareholders. The first fund to submit the question to its shareholders processed its proxy statement through the Commission in the late summer of 1962 with little difficulty, and a comparatively short proxy statement was sent to its shareholders. The proxy statement for the second fund, initially submitted in February 1963, after the change in the staff's position, took approximately six months to clear and in its final form was some thirty-eight pages, $3 \frac{1}{2}$ " $\times 81 / 2$ ", more than one and one-half times the length of the proxy statement for the first fund. This proxy statement was, however, small compared to a proxy statement for another unaffiliated fund, which ran to twenty-four pages, $8^{\prime \prime} \times 9^{1 / 2}{ }^{\prime \prime}$.

The size and complexity of these proxy statements should be viewed against the comment by Judge Riffind in Doyle v. Milton, 73 F. Supp. 28I, 285 (S.D.N.Y. 1947), that "to drench the stockholder with a lood of information may defeat the very purpose of the rule."

It would be interesting to develop comparative statistics on shareholder response to the later more detailed proxy statements as opposed to the earlier and shorter proxy statements. In the case of the two related funds which submitted new management contracts before and after the change in the staff's position, the second fund's proxy statement contained substantially more financial data, some quite complex. The additional financial data does not appear to have had any effect on stockholders' attitudes. In each case approximately the same percentage of the outstanding shares were present by proxy or otherwise, and the percentages of shares voted for each new contract were substantially identical. This is not, of course, a sufficiently large sample from which to draw any firm conclusions. The experience of these two funds suggests, however, that the inclusion of additional material in the second proxy statement had little, if any, effect on the shareholders' meeting.

${ }^{57}$ I7 C.F.R. $\$ 270.20 a-1-.20 a-3$ (Supp. 1963). Proxy rule 20 a was originally promulgated in 1940, shortly after the passage of the Investment Company Act. Solicitation of Proxies, Consents and Authorizations, SEC Investment Company Act Release No. 9, 5 Fed. Reg. 4366 (1940). All that it did was to apply Regulation X-I 4 to securities issued by investment companies. To date, it has been amended only once, in 1960 .

${ }^{8}$ Notice of Proposed Rules Relating to Proxy Statements, SEC Investment Company Act Release No. 2962, 25 Fed. Reg. 252 (Ig60).

${ }^{\circ 0}$ Revised Proxy Rules for Investment Companies, SEC Investment Company Act Release No. 2978, 25 Fed. Reg. 1865 (1960). 
information which had not been systematically collected in the past because there was no previously announced proxy requirement, formal or informal, and because there was no need, extrinsic to the proxy rules, for such information. ${ }^{00}$

It can, of course, be argued, as the staff did, that there is a substantial difference between submitting an advisory contract to shareholders for approval and submitting such a contract after settlement of shareholder litigation and that this difference justifies the decision to require the inclusion of additional financial information, notwithstanding any added expense or delay. However, putting an advisory contract to the shareholders after court approval of a settlement is not equivalent to submitting the settlement itself; and the insistence on the inclusion of additional financial information cannot be justified on the theory that the shareholders are being asked to approve the settlement. Moreover, each settlement had been reviewed by a court in an independent judicial inquiry, which included a review of the new contract, and before any new contract had been submitted to the shareholders the court had concluded that the settlement was fair and in their best interest. This judicial examination bore, at least indirectly, on the propriety of the terms of the contract. Hence, it would seem that there is less need for this type of financial information where advisory contracts are submitted after settlement of stockholder litigation than where such information is not required.

\section{Conclusion}

The flexible and informal administration by the Cornmission and its staff of the proxy rules is an example of the adaptability of the process of administrative law to the solution of difficult and dynamic problems. The nature of the Commission's task in enforcing the proxy rules-disclosure of relevant information-is one which is peculiarly suited to flexible and informal procedures seeking to enforce minimum standards. Such procedures could not be applied, for example, to rate-making proceedings.

Thus, the Commission's experience with the proxy rules may not provide a specific guide for use by other agencies in the performance of different administrative tasks. However, that experience illustrates certain general principles pertinent to discussion of the role of administrative law and the function of the administrator, and illuminates dangers inherent in the exercise of the supervisory power. If the proxy rules are to continue as an example of an effective instrument fashioned through wise administration, the Commission must constantly be on guard against abuse of its discretion and informal power.

${ }^{80}$ On March 18, 1964, the Commission released for comment a proposed revision of Rule 20a which, if adopted, would require the inclusion of certain profit and loss data of the investment advisor in proxy materials of investment companies in certain circumstances. Proposal to Amend Rule 20a-2 Under the Investment Company Act with Respect to Disclosure of Certain Financial and Other Information in Proxy Statements Relating to Registered Investment Companies, SEC Investment Company Act Release No. 3931, March 18, 1964. 